Benha Veterinary Medical Journal
Official Journal Issued by
Faculty of
Veterinary Medicine Journal homepage: https://bvmj.journals.ekb.eg/

Original Paper

\title{
Microbiological status of chicken cuts and its products
}

\author{
Fahim A. Shaltout ${ }^{1}$, Marrionet Z. Nasief ${ }^{2}$, Lamiaa M. Lotfy ${ }^{3}$, Bossi T. Gamil ${ }^{4}$

 \\ ${ }^{2}$ Food Hygiene Dep., Animal Health Res., Benha \\ ${ }^{3}$ Dept. of Economics, Faculty of Specific Education, Kafer el-sheikh University \\ ${ }^{4}$ General Organization Veterinary for research.
}

\section{ARTICLE INFO}

\section{Keywords}

Cocked chicken meat cuts

Half cocked

Microbiology

Raw

Received 30/09/2019

Accepted 27/10/2019

Available On-Line

$12 / 05 / 2020$

\begin{abstract}
A total of 90 random samples of raw, half cooked (which were exposed to moderate heat treatment) and cooked wings, breast and thigh were collected from supermarkets and restaurant at Qalyubia governorate for evaluation to the microbial status. The obtained results indicated that the mean values of Aerobic plate count for raw samples (wings, breast and thigh) were $4.0 \times 10^{6} \pm 0.3 \times 10^{6}, 4.5$ $\times 10^{6} \pm 0.5 \times 10^{6}, 5.7 \times 10^{6} \pm 0.4 \times 10^{6}$ and for the half cooked were $3.6 \times 10^{5} \pm 0.2 \times 10^{5}$, $5.1 \times 10^{5} \pm 0.2 \times 10^{5}, 6.3 \times 10^{5} \pm 0.2 \times 10^{5}, 1.7 \times 10^{4} \pm 0.1 \times 10^{4}, 2.1 \times 10^{4} \pm 0.2 \times 10^{4}, 2.3 \times 10^{4}$ $\pm 0.2 \times 10^{4}$ respectively. The total Enterobacteriaceae counts of raw (wings, breast and thigh) were $32.3 \times 105 \pm 1.4 \times 105,18.0 \times 105 \pm 1.7 \times 105,23.3 \times 10 \pm 1.4 \times 105$, for half

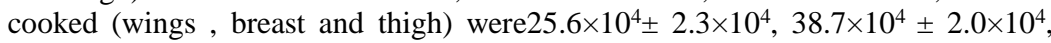
$30.7 \times 10^{4} \pm 3.01 \times 10^{4}$ and for cooked wings, breast and thigh) were $23.7 \times 10^{4} \pm$ $1.2 \times 10^{4}, 34.3 \times 104 \pm 2.0 \times 10^{4}, 17.1 \times 10^{4} \pm 1.1 \times 10^{4}$. Total coliforms mean values for raw samples were $37.3 \times 10^{2} \pm 0.8 \times 10^{2}, 21.6 \times 10^{2} \pm 2.4 \times 10^{2}, 27.7 \times 10^{2} \pm 4.4 \times 10^{2}$ for half cooked were $10.3 \times 10^{2} \pm 0.8 \times 10^{2}, 12.3 \times 102 \pm 0.8 \times 10^{2}, \quad 14.0 \times 10^{2} \pm 1.2 \times 10^{2}$, forcooked $12.3 \times 10^{2} \pm 1.4 \times 10^{2}, 12.0 \times 10^{2} \pm 1 ., 5 \times 10^{2}, 15.3 \times 10^{2} \pm 2.6 \times 10^{2}$,respectively .Incidence of E. coli isolated from raw samples were $20 \%, 10 \%$ and $30 \%$ and for half cooked were $10 \%, 10 \%$ and $20 \%$ respectively. Salmonella spp. were isolated only from raw wings The total staphylococcus aureus for raw (wings, breast and high) were $21.7 \times 10^{2} \pm 2.0 \times 10^{2}, 24.0 \times 10^{2} \pm 5.2 \times 10^{2}, 25.3 \times 10^{2} \pm 4.2 \times 10^{2}$,for half cooked (wings, breast and thigh) were $47.3 \times 10^{2} \pm 2.7 \times 10^{2}, 41.7 \times 10^{2} \pm 2.0 \times 10^{2}$, $50.0 \times 10^{2} \pm 3.2 \times 10^{2}$, and for cooked wings , breast and thigh were $22.3 \times 10 \pm 0.9 \times 10$, $12.3 \times 10 \pm 1.5 \times 10,14.7 \times 10 \pm 1.2 \times 10$. The mean values of total yeast and mould in raw samples breast and thigh were $20.3 \times 10 \pm 1.0 \times 10,41.2 \times 10 \pm$ $1.2 \times 10$ respectively. The present study concluded that there is a need to educate consumers, food handlers and all others who have access to food about the importance of hygiene and it is necessary to cook food properly.
\end{abstract}

\section{INTRODUCTION}

Chicken meat and chicken meat products are very popular food throughout the world since they are delicious and nutritious food, characterized by good flavor and easily digestion (Smith, 2001).

Microbial contamination of poultry carcasses and their cuts are a natural result of different procedures necessary to produce retail products from living birds. Contamination of poultry meat products may be occurred throughout initial processing, packaging and storage until the product is sufficiently cooked and consumed. Heavy bacterial loads enter the processing operations with the living birds and these bacteria can be disseminated throughout the plant during processing (Zhang et al., 2001).

Chicken is an important low-cost source of animal protein, so its consumption is increased (Cohen et al., 2007). Poultry contamination mostly occurs during slaughter and processing due to contact of carcass with intestinal content, feet and feathers (Allerberger et al., 2003).

Presence of large numbers of microorganisms in raw meat, there will be changes such that it becomes unappealing and unsuitable for human consumption (Fung et al 2010). Various hazards kinds of microorganisms from different sources starting from the chicken carcass itself and

* Corresponding author: Prof. Fahim A. Shaltout. Food Hygiene Dep., Fac. Vet. Med., Benha Univ., Egypt 
throughout the processing plant contaminated poultry meat and its products (Shaltout et al., 2018).

Fresh carcasses have higher coliforms, faecal coliforms, $E$. coli and $S$. aureus counts than the frozen one. Lack of sanitary measures in traditional poultry shops lead to contamination of chicken carcasses as cross contamination occurs during processing (Khalafalla, 2015).

Total aerobic plate count is used as indicator for bacterial population on the sample but not differentiate types of bacteria (APHA, 2001). Aerobic plate counts can be useful to indicate quality, shelf life and post heat-processing contamination (GuaranTek Analytic Labo-ratories, 2003).

Enterobacteriaceae count may be used as indicator for enteric contamination and as assessment of the general hygienic status of a food product (HPA, 2004). Sources of coliforms in meat are soild hands, knives used for cutting, and contaminated water (Yadav et al., 2006). Fecal coliforms had been used as indicator for fecal contamination.

Escherichia coli is a very important indicator for fecal contamination and its presence in poultry meat reveal to improper sanitation (Synge, 2000).

Salmonella identified as etiological agent of food born outbreaks (Siqueira et al., 2003). Salmonella was reported as the most frequent food born pathogen worldwide (Capita et al., 2007). Also, Salmonellae may undergo multiplication steps along food chain including production, processing, distribution, marketing, handling and preparation (Dookeran et al., 2012).

Presence $S$. aureus in poultry meat indicate non-hygienic habits during slaughter, contamination with intestinal contents or skin of the carcass and through contaminated knives (Javid et al 2014).

The aim of the study was to evaluate microbiological status of chicken meat and its product.

\section{MATERIAL AND METHODS}

\subsection{Collection of samples:}

A total of 90 random fresh, half cooked treated and cooked samples (30 of each) and each type represent wings, breast and thigh samples (10 of each) were collected from local supermarkets and retail shops in Qalyubia governorate. The collected samples were transferred directly to the laboratory, in an icebox under complete aseptic conditions to evaluate chemical and bacteriological quality.

\subsection{Preparation of samples:}

\subsection{Bacteriological quality evaluation}

2.3.1. Determination of Aerobic plate count " $A P C$ " (ISO, 2013)

2.3.2. Determination of Total Enterobacteriaceae count (APHA 2001)

2.3.3. Determination of Total coliform count (ISO, 2004):

2.3.4. Isolation and identification of E. coli (ISO 2001):

2.3.4.1. Morphological examination:

2.3.4.1.1. Gram's Stain (Cruickshank et al., 1975):

2.3.4.1.2. Motility test (Mac Faddin, 2000):

2.3.4.2. Biochemical identification of_E. coli (Mac

Faddin, 2000):

Indole, methyl red, voges proskaur, citrate utilization, hydrogen sulphide, Gelatin hydrolysis, urease,
Eijkman, nitrate reduction and sugar fermentation tests were applied. Nutrient gelatin stab cultures were grown at room temperature and observed daily after cooling to about $18^{\circ} \mathrm{C}$. E. coli showed a negative reaction.

2.3.4.3. Serological Identification.

2.3.5. Determination of Total count of S. aureus (ISO, 2017):

2.3.5.1. Morphological examination.

2.3.5.2. Biochemical identification.

2.3.6. Isolation and identification of Salmonellae (ISO 2001):

2.3.6.1. Morphological examination

2.3.6.2. Biochemical identification.

2.3.6.3. Serological identification.

It was carried out according to Kauffman - White scheme for the determination of Somatic $(\mathrm{O})$ and flagella (H) antigens using Salmonella antiserum (DENKA SEIKEN Co., Japan).

\section{RESULTS AND DISCUSSION}

Chicken meat contamination mostly occur during slaughter and processing stages due to contact of carcass mainly with intestinal content, feet, and feathers (Allerberger et al., 2003). Presence of large number of microorganisms in raw meat, there will be changes such that it becomes unfit for human consumption or even harmful to consumers. (Fung et al., 2010).

The total aerobic plate count gives an idea about hygienic measures applied through processing. For that, it is the most reliable method for detection of sanitary levels of proper processing, storage and marketing of food products. The obtained results in APC in raw wings ,breast and thigh were $5.2 \times 10^{3}$ to $4.2 \times 10^{7} \mathrm{cfu}$ with mean $4.0 \times 10^{6} \pm 0.3 \times 10^{6}$, $5.3 \times 10^{3}$ to $2.0 \times 10^{7}$ with mean $4.5 \times 10^{6} \pm 0.5 \times 10^{6}$ and $6.1 \times 10^{3}$ to $3.3 \times 10^{7}$ with mean $5.7 \times 10^{6} \pm 0.4 \times 10^{6}$, respectively. The result revealed high values than Mahmoud and Hamouda Seham (2006), Saikia and Joshi (2010), Rban and Fairoze (2011). Hassan-Ola (2015) and Fathy-Ola (2015) but higher values obtained with Chaiba et al. (2001), Vural et al. (2006), Saif et al. (2015) and Farhat et al. (2019).

The processing of carcass into more parts lead to further spread of contamination by exposing more carcass surface to contamination if the same cutting tables and knives are used. The obtained APC count for half cooked wings, breast and thigh were $3.2 \times 10^{3}$ to $4.1 \times 10^{6}$ with mean $3.6 \times 10^{5} \pm 0.2 \times 10^{5}, 4.8 \times 10^{3}$ to $5.5 \times 10^{6}$ with mean $5.1 \times 10^{5} \pm$ $0.2 \times 10^{5}$ and $1.7 \times 10^{3}$ to $2.5 \times 10^{6}$ with mean $6.3 \times 10^{5}$ $\pm 0.2 \times 10^{5}$, respectively. This obtained result is lower than that obtained from Shaltout (2006). and Saad et al. (2015). The contamination of half cooked chicken meat product samples may be due to inadequate sanitary condition during processing ,bad handling, dirty equipment, polluted water, contaminated cold stores and temperature fluctuation during storage(Saad et al.,1989, Refaie et al., 1991,Farghaly 1998).

The obtained APC count in cooked wings, breast and thigh $1.3 \times 10^{2}$ to $2.2 \times 10^{4}$ with mean $1.7 \times 10^{4} \pm 0.1 \times 10^{4}, 1.7 \times 10^{2}$ to $2.5 \times 10^{4}$ with mean $2.1 \times 10^{4} \pm 0.2 \times 10^{4}$ and $2.1 \times 10^{2}$ to $2.6 \times 10^{4}$ with mean $2.3 \times 10^{4} \pm 0.2 \times 10^{4}$, respectively. Higher results obtained from Noha and Gehad (2005), Rady et al. (2011) and Fathy Ola (2014). 
According to the safe permissible limit stipulated by EOS(2005)NO.(1651-2005)for APC in raw poultry products not exceed $10^{5} \mathrm{cfu} / \mathrm{g}$, No.(3493-2005)for half cooked samples(heat treated products) not exceed $10^{4}$ and No.(3493-2005) for cooked samples not exeed $10^{4}$,it was indicated that $20 \%, 30 \%, 20 \%, 30 \%, 40 \%, 40 \%, 10 \%, 20 \%$ and $10 \%$ of the examined samples raw wing ,breast, thigh, half cooked wing, breast ,thigh and cocked wing ,breast and thigh , respectively were not in accordance with this limit (Table 1).

Moreover, Enterobacteriaceae count in table (2) for raw samples (wing, breast and thigh ) $30 \times 10$ to $35 \times 10^{5}$ with mean $32.3 \times 10^{5} \pm 1.4 \times 10^{5}, 15 \times 10$ to $27 \times 10^{5}$ with mean $18.0 \times 10^{5} \pm 1.7 \times 10^{5}$ and $22 \times 10$ to $35 \times 10^{5}$ with mean 24.3 $\times 10^{5} \pm 1.4 \times 10^{5}$, respectively. While for half cooked (wing, breast and thigh) were $22 \times 10^{4}$ to $30 \times 10^{4}$ with mean $25.6 \times 10^{4} \pm 2.3 \times 10^{4}, 35 \times 10^{4}$ to $42 \times 10^{4} \quad$ with mean $38.7 \times 10^{4} \pm 2.0 \times 10^{4}$ and $24 \times 10^{4}$ to $35 \times 10^{4}$ with mean $30.7 \times 10^{4} \pm 3.01 \times 10^{4}$, respectively.

Finally, the result of cooked samples (wings, breast and thigh) were $21 \times 10^{4}$ to $26 \times 10^{4}$ with mean $23.7 \times 10^{4} \pm 1.2 \times 10^{4}$
, $30 \times 10^{4}$ to $38 \times 10^{4}$ with mean $34.3 \times 10^{4} \pm 2.0 \times 10^{4}$ and $12 \times 10^{4}$ to $22 \times 10^{4}$ with mean $17.1 \times 10^{4} \pm 1.1 \times 10^{4}$ respectivelly.

The result is higher that obtained with Vural (2006), Nwar (2007) , El-Deeb et al. (2011) and Fathyola (2015). Enterobacteriaceae group has an epidemiological importance as some of its members are pathogenic and may cause serious infections and food poisoning to man. Moreover, the total Enterobacteriaceae count can be taken as indicative of possible enteric contamination in the absence of coliform bacteria (Pogorelova et al., 1993). Consequently, the total Enterobacteriaceae count can be applied to monitor the hygienic level during handling of chicken meat products. The examined sample showed that raw chicken samples were more contaminated, and this may be due to exposure of samples to fecal contamination by worker's hands during evisceration.

The result obtained in table(3) for raw samples( wing, breast and thigh )were $12 \times 10$ to $54 \times 10^{2}$ with mean $37.3 \times 10^{2} \pm 0.8 \times 10^{2}, 17 \times 10$ to $25 \times 10^{2}$ with mean $21.6 \times 10^{2}$ $\pm 2.4 \times 10^{2}$ and $19 \times 10$ to $33 \times 10^{2}$ with mean $27.7 \times 10^{2}$ $\pm 4.4 \times 10^{2}$, respectively.

\begin{tabular}{|c|c|c|c|c|c|c|c|c|c|c|}
\hline \multirow[t]{2}{*}{ Samples } & \multirow[t]{2}{*}{$\begin{array}{c}\text { No. of } \\
\text { samples }\end{array}$} & \multirow[t]{2}{*}{ Min. } & \multirow[t]{2}{*}{ Max. } & \multirow[t]{2}{*}{ Mean \pm S.E.M $*$} & \multirow[t]{2}{*}{$\mathrm{MRL}^{1}$} & \multirow[t]{2}{*}{$\begin{array}{l}\text { No. of positive } \\
\text { samples }\end{array}$} & \multicolumn{2}{|c|}{$\begin{array}{l}\text { Accepted } \\
\text { samples }\end{array}$} & \multicolumn{2}{|c|}{$\begin{array}{c}\text { Unaccepted } \\
\text { samples }\end{array}$} \\
\hline & & & & & & & No. & $\%$ & No. & $\%$ \\
\hline \multicolumn{11}{|l|}{ Raw samples } \\
\hline Wings & 10 & $5.2 \times 10^{3}$ & $4.2 \times 10^{7}$ & $4.0^{\mathrm{a}} \times 10^{6} \pm 0.3 \times 10^{6}$ & \multirow{3}{*}{$\begin{array}{c}10^{5} \\
E_{. S} \\
1651 / 2005\end{array}$} & 10 & 8 & 80 & 2 & 20 \\
\hline Breast & 10 & $5.3 \times 10^{3}$ & $2.0 \times 10^{7}$ & $4.5^{\mathrm{a}} \times 10^{6} \pm 0.5 \times 10^{6}$ & & 10 & 7 & 70 & 3 & 30 \\
\hline Thigh & 10 & $6.1 \times 10^{3}$ & $3.3 \times 10^{7}$ & $5.7^{\mathrm{a}} \times 10^{6} \pm 0.4 \times 10^{6}$ & & 10 & 8 & 80 & 2 & 20 \\
\hline \multicolumn{11}{|l|}{ Half cooked samples } \\
\hline Wings & 10 & $3.2 \times 10^{3}$ & $4.1 \times 10^{6}$ & $3.6^{\mathrm{b}} \times 10^{5} \pm 0.2 \times 10^{5}$ & $\begin{array}{l}10^{4} \\
E . S\end{array}$ & 10 & 7 & 57 & 3 & 30 \\
\hline Breast & 10 & $4.8 \times 10^{3}$ & $5.5 \times 10^{6}$ & $5.1^{\mathrm{a}} \times 10^{5} \pm 0.2 \times 10^{5}$ & $3493 / 2005$ & 10 & 6 & 50 & 4 & 40 \\
\hline Thigh & 10 & $1.7 \times 10^{3}$ & $2.5 \times 10^{6}$ & $6.3^{\mathrm{a}} \times 10^{5} \pm 0.210^{5}$ & & 10 & 6 & 33 & 4 & 40 \\
\hline Cooked samples & & & & & & 10 & & & & \\
\hline Wings & 10 & $1.3 \times 10^{2}$ & $2.2 \times 10^{4}$ & $1.7^{\mathrm{c}} \times 10^{4} \pm 0.1 \times 10^{4}$ & \multirow{3}{*}{$\begin{array}{c}10^{4} \\
E . S \\
3493 / 2005\end{array}$} & 10 & 9 & 86 & 1 & 10 \\
\hline Breast & 10 & $1.7 \times 10^{2}$ & $2.5 \times 10^{4}$ & $2.1^{\mathrm{b}} \times 10^{4} \pm 0.2 \times 10^{4}$ & & 10 & 8 & 80 & 2 & 20 \\
\hline Thigh & 10 & $2.1 \times 10^{2}$ & $2.6 \times 10^{4}$ & $2.3^{b} \times 10^{4} \pm 0.2 \times 10^{4}$ & & 10 & 9 & 75 & 1 & 10 \\
\hline
\end{tabular}

Table 2 Statistical analytical results of Enterobacteriaceae (cfu/g) in examined chicken meat samples $(\mathrm{n}=30)$.

\begin{tabular}{|c|c|c|c|c|c|c|c|c|c|c|}
\hline \multirow{2}{*}{$\begin{array}{l}\text { Samples } \\
\text { Raw samples }\end{array}$} & \multirow[t]{2}{*}{ No. of samples } & \multirow[t]{2}{*}{ Min. } & \multirow[t]{2}{*}{ Max. } & \multirow[t]{2}{*}{ Mean \pm S.E.M ${ }^{*}$} & \multirow[t]{2}{*}{$\mathrm{MRL}^{1}$} & \multirow{2}{*}{$\begin{array}{c}\text { No. of positive } \\
\text { samples }\end{array}$} & \multicolumn{2}{|c|}{ Accepted samples } & \multicolumn{2}{|c|}{ Unaccepted samples } \\
\hline & & & & & & & No. & $\%$ & No. & $\%$ \\
\hline Breast & 10 & $15 \times 10$ & $27 \times 10^{5}$ & $18.0^{\mathrm{b}} \times 10^{5} \pm 1.7 \times 10^{5}$ & \multirow{2}{*}{$\begin{array}{c}10^{2} \\
\text { C.F.S/2014 }\end{array}$} & 9 & 7 & 70 & 3 & 30 \\
\hline Thigh & 10 & $22 \times 10$ & $35 \times 10^{5}$ & $24.3^{\mathrm{b}} \times 10^{5} \pm 1.4 \times 10^{5}$ & & 6 & 8 & 80 & 2 & 20 \\
\hline Breast & 10 & $35 \times 10$ & $42 \times 10^{4}$ & $38.7^{\mathrm{a}} \times 10^{4} \pm 2.0 \times 10^{4}$ & \multirow{2}{*}{$\begin{array}{c}10^{2} \\
\text { C.F.S/2014 }\end{array}$} & 6 & 9 & 90 & 1 & 10 \\
\hline Thigh & 10 & $24 \times 10$ & $35 \times 10^{4}$ & $30.7^{\mathrm{b}} \times 10^{4} \pm 3.01 \times 10^{4}$ & & 2 & 8 & 80 & 2 & 20 \\
\hline \multicolumn{11}{|c|}{ Cooked samples } \\
\hline Wings & 10 & $21 \times 10$ & $26 \times 10^{4}$ & $23.7^{\mathrm{b}} \times 10^{4} \pm 1.2 \times 10^{4}$ & \multirow{2}{*}{$\begin{array}{c}10^{2} \\
\text { C.F.S/2014 }\end{array}$} & 9 & 7 & 70 & 3 & 30 \\
\hline Breast & 10 & $30 \times 10$ & $38 \times 10^{4}$ & $34.3^{\mathrm{a}} \times 10^{4} \pm 2.0 \times 10^{4}$ & & 3 & 9 & 90 & 1 & 10 \\
\hline
\end{tabular}

While for half cooked samples $19 \times 10$ to $12 \times 10^{2}$ to with mean $10.3 \times 10^{2} \pm 0.8 \times 10^{2}, 9 \times 10$ to $14 \times 10^{2}$ with mean $12.3 \times 10^{2} \pm 0.8 \times 10^{2}$ and $12 \times 10$ to $16 \times 10^{2}$ with mean 14.0 $\times 10^{2} \pm 1.2 \times 10^{2}$, respectively. Moreover, for cooked (wing, breast and thigh) were $10 \times 10$ to $15 \times 10^{2}$ with mean $12.3 \times 10^{2} \pm 1.4 \times 10^{2}, 9 \times 10$ to $14 \times 10^{2}$ with mean $12.0 \times 10^{2} \pm$
$1.5 \times 10^{2}$ and $11 \times 10$ to $20 \times 10^{2}$ with mean $15.3 \times 10^{2} \pm$ $2.6 \times 10^{2}$, respectively.

The obtained results nearly similar to obtained by Oumokhtar (2000) and Huong et al. (2009) but lower than obtained with Hegazy (1995), Javadi and Safaramashaei (2004), Vural et al. (2006) and Zakaria-Marwa (2015). 
Detection of coliform is used as a general indicator of sanitary condition in food-processing environment or indication of water pollution (Feng et al., 2002).

The contamination with coliforms may occur during slaughtering, cutting, or dressing of carcasses. Soiled hands, shopping blocks or knives used for handling and cutting, or contaminated water were considered as sources of coliforms in meat (Yadav et al., 2006). Therefore, the results obtained in table $(4 \& 5)$ for raw samples revealed that wings with an incidance $20 \%$,the two strains isolated were $\mathrm{O}_{55}: \mathrm{H}_{7}$ and $\mathrm{O}_{125}: \mathrm{H}_{18},(10 \%)$ for breast sample with serotype $\mathrm{O}_{55}: \mathrm{H}_{7}$ and for thigh (30\%)with strains $\mathrm{O}_{114}: \mathrm{H}_{21}$ and $\mathrm{O}_{125}: \mathrm{H}_{18}$

Half cooked showed that wings $10 \%$ with strain $\mathrm{O}_{125}: \mathrm{H}_{18}$, breast $(10 \%)$ with strain $\mathrm{O}_{114}: \mathrm{H}_{21}$ and for thigh $20 \%$ with strains $\mathrm{O}_{114}: \mathrm{H}_{21}$ and $\mathrm{O}_{55}: \mathrm{H} 7$
The result is nearly to obtained by Hossam (2012), higher than obtained by Lee et al. (2009) and the higher result obtained by Huong et al (2009), Zakaria-Marwa (2015) and Hassan Ola (2015). The presence of E. coli in the examined samples is an indicator for unhygienic conditions. E. coli strains are normal commensals in gut of animals so the carcass may be contaminated with these bacteria during slaughter process. Manual evisceration and unsatisfactory hygienic measures of handling and processing are the mean reasons for contamination of chicken meat with $\mathrm{E}$. coli (Whyte et al., 2014). Furthermore, results recorded in table (6) showed that raw wings were infected with $10 \%$ by strain $S$. Enteritidis . This strain considered as one of main reasons of food borne outbreaks throughout the world (Herikstad et al., 2002).

\begin{tabular}{|c|c|c|c|c|c|c|c|c|c|c|}
\hline \multirow{2}{*}{$\begin{array}{l}\text { Samples } \\
\text { Raw samples }\end{array}$} & \multirow{2}{*}{$\begin{array}{l}\text { No. } \\
\text { of samples }\end{array}$} & \multirow[t]{2}{*}{ Min. } & \multirow[t]{2}{*}{ Max. } & \multirow[t]{2}{*}{ Mean \pm S.E.M* } & \multirow[t]{2}{*}{ MRL $^{1}$} & \multirow{2}{*}{$\begin{array}{l}\text { No. of positive } \\
\text { samples }\end{array}$} & \multicolumn{2}{|c|}{ Accepted samples } & \multicolumn{2}{|c|}{ Unaccepted samples } \\
\hline & & & & & & & No. & $\%$ & No. & $\%$ \\
\hline Wings & 10 & $12 \times 10$ & $54 \times 10^{2}$ & $37.3^{\mathrm{a}} \times 10^{2} \pm 0.8 \times 10^{2}$ & \multirow{3}{*}{$\begin{array}{l}10^{2} \\
\text { E.S } 1651 / 2005\end{array}$} & 9 & 6 & 60 & 4 & 40 \\
\hline Breast & 10 & $17 \times 10$ & $25 \times 10^{2}$ & $21.6^{\mathrm{a}} \times 10^{2} \pm 2.4 \times 10^{2}$ & & 4 & 9 & 90 & 1 & 10 \\
\hline Thigh & 10 & $19 \times 10$ & $33 \times 10^{2}$ & $27.7^{\mathrm{a}} \times 10^{2} \pm 4.4 \times 10^{2}$ & & 7 & 6 & 60 & 4 & 40 \\
\hline \multicolumn{11}{|c|}{ Half cooked samples } \\
\hline Wings & 10 & $19 \times 10$ & $12 \times 10^{2}$ & $10.3^{\mathrm{b}} \times 10^{2} \pm 0.8 \times 10^{2}$ & \multirow{3}{*}{$\begin{array}{l}10^{2} \\
\text { E.S 3493/2005 }\end{array}$} & 3 & 9 & 90 & 1 & 10 \\
\hline Breast & 10 & $9 \times 10$ & $14 \times 10^{2}$ & $12.3^{\mathrm{b}} \times 10^{2} \pm 0.8 \times 10^{2}$ & & 2 & 8 & 80 & 2 & 100 \\
\hline Thigh & 10 & $12 \times 10$ & $16 \times 10^{2}$ & $14.0^{\mathrm{b}} \times 10^{2} \pm 1.2 \times 10^{2}$ & & 4 & 8 & 80 & 2 & 20 \\
\hline \multicolumn{11}{|c|}{ Cooked samples } \\
\hline Wings & 10 & $10 \times 10$ & $5 \times 10^{2}$ & $12.3^{\mathrm{b}} \times 10^{2} \pm 1.4 \times 10^{2}$ & \multirow{3}{*}{$\begin{array}{l}10^{2} \\
\text { E.S3493/2005 }\end{array}$} & 2 & 9 & 90 & 1 & 10 \\
\hline Breast & 10 & $9 \times 10$ & $14 \times 10^{2}$ & $12.0^{\mathrm{b}} \times 10^{2} \pm 1.5 \times 10^{2}$ & & 1 & 10 & 100 & - & - \\
\hline Thigh & 10 & $11 \times 10$ & $20 \times 10^{2}$ & $15.3^{\mathrm{b}} \times 10^{2} \pm 2.6 \times 10^{2}$ & & 1 & 10 & 100 & - & - \\
\hline
\end{tabular}

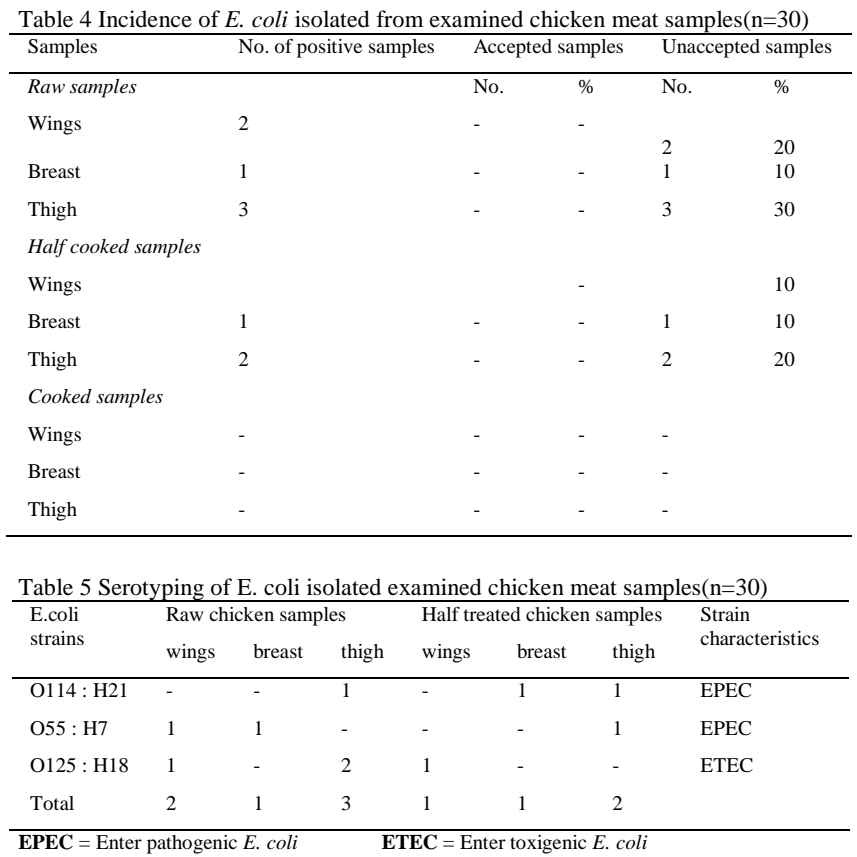

The presence of these pathogens may be due to contamination during processing or due to poor handling (Kagambega et al., 2012). Principal sources of Salmonella organisms are dust, food handlers, pet animals, insects, rodents, birds and the air (Wabec, 2002).
The presence of Salmonella in chicken meat may be attributed to contamination during slaughtering and / or processing from worker's hands (Cardoso et al., 1997). Organic matters scattered on the bird surface may harbor Salmonella and act as a source of contamination to scalding tanks, therefore, facilitate cross contamination 
between chicken. Rubber fingers of plucking machine may have several cracks carrying organic matter and act as source of cross- contamination between chickens moreover, during evisceration step cross-contamination may occur through escape of gut content (Berrang et al., 2011).

The higher result obtained from Ruban et al. (2010), Nawar (2007) and Ruban and Fairoze (2011). Lower results obtained by Samaha et al. (2012) and Zaki et al., 2013).

The results recorded in table (7) revealed that raw samples (wings, breast and thigh) ranged from $18 \times 10$ to $25 \times 10^{2}$ with mean $21.7 \times 10^{2} \pm 2.0 \times 10^{2}, 15 \times 10$ to $33 \times 10^{2}$ with mean $24.0 \times 10^{2} \pm 5.2 \times 10^{2}$ and $17 \times 10$ to $31 \times 10^{2}$ with mean $25.3 \times 10^{2}$ to $4.2 \times 10^{2}$, respectively.

While for half cooked wings, breast and thigh were $12 \times 10$ to $51 \times 10^{2}$ with mean $47.3 \times 10^{2} \pm 2.7 \times 10^{2}, 11 \times 10$ to $45 \times 10^{2}$ with mean $41.7 \times 10^{2} \pm 2.0 \times 10^{2}$ and $15 \times 10$ to $56 \times 10^{2}$ with mean $50.0 \times 10^{2} \pm 3.2 \times 10^{2}$, respectively.

Meanwhile, for cooked wings, breast and thigh $8 \times 10$ to $24 \times 10$ with mean $22.3 \times 10 \pm 0.9 \times 10.5 \times 10$ t0 $15 \times 10$ with mean $12.3 \times 10 \pm 1.5 \times 10$ and $6 \times 10$ to $17 \times 10$ with mean $14.7 \pm 1.2 \times 10$. Higher results were obtained from
Cohen et al. (2007) and HeetunIrfan (2015) but lower results were obtained by Kozacinski et al. (2006).

Staphylococcus aureus was recognized as the second most common pathogen isolated from food samples (Hotee, 2011). Chicken meat becomes contaminated with Staphylococcus, usually through expulsion of these organisms into the air by infected humans through sneezing, coughing, breathing or talking (Wabeck, 2002).

Moreover, the results reported in table (8) for total yeast and mould count regarding for raw breast and thigh to $15 \times 10$ to $40 \times 10$ with mean $20.3 \times 10 \pm 1.0 \times 10$ and $25 \times 10$ to $63 \times 10$ with mean $41.2 \times 10 \pm 1.2 \times 10$, respectively. According to E.S five samples of raw breast were unaccepted, and 3 samples of raw thigh were unaccepted. The half cooked and cooked samples were less than 10 for all examined samples. Yeast and mould present normally in nature. The ability of the yeast species to grow at low temperatures. Yeasts may play a more significant role in the spoilage of poultry meat products (Deak, 2001).

\begin{tabular}{|c|c|c|c|c|c|c|c|c|}
\hline \multirow[t]{2}{*}{ samples } & \multirow[t]{2}{*}{ No. of samples } & \multirow[t]{2}{*}{$\mathrm{MRL}^{1}$} & \multirow[t]{2}{*}{ No . of positive samples } & \multicolumn{2}{|c|}{ Accepted samples } & \multicolumn{2}{|c|}{ Unaccepted samples } & \multirow[t]{2}{*}{ Salmonella strain } \\
\hline & & & & No. & $\%$ & No. & $\%$ & \\
\hline \multicolumn{9}{|l|}{ Raw samples } \\
\hline Wings & 10 & & 1 & 9 & 90 & 1 & 10 & $\begin{array}{l}\text { S. Enteritidis } \\
\mathrm{O} 1,4,5,12 \text { H i : } 1,2\end{array}$ \\
\hline Breast & 10 & E.O.S $1651 / 2005$ & - & 10 & 100 & - & - & - \\
\hline Thigh & 10 & & - & 10 & 100 & - & - & - \\
\hline Half cooked samples & & & & & & & & - \\
\hline Wings & 10 & \multirow{3}{*}{$\begin{array}{c}\text { free } \\
\text { E.0.S 3493/2005 }\end{array}$} & - & 10 & 100 & - & - & - \\
\hline Breast & 10 & & - & 10 & 100 & - & - & - \\
\hline Thigh & 10 & & - & 10 & 100 & - & - & - \\
\hline Cooked samples & & & - & 10 & 100 & - & - & - \\
\hline Wings & 10 & \multirow{3}{*}{$\begin{array}{c}\text { free } \\
\text { E.0.S } 3493 / 2005\end{array}$} & - & 10 & 100 & - & - & - \\
\hline Breast & 10 & & - & 10 & 100 & - & - & - \\
\hline Thigh & 10 & & - & 10 & 100 & - & - & - \\
\hline
\end{tabular}

Table 7 Statistical analytical results of Total staphylococcus aureus $(\mathrm{cfu} / \mathrm{g})$ in examined chicken meat samples $(\mathrm{n}=30)$

\begin{tabular}{|c|c|c|c|c|c|c|c|c|c|c|}
\hline \multirow[t]{2}{*}{ Samples } & \multirow[t]{2}{*}{ No. of samples } & \multirow[t]{2}{*}{ Min. } & \multirow[t]{2}{*}{ Max. } & \multirow[t]{2}{*}{ Mean \pm S.E.M ${ }^{*}$} & \multirow[t]{2}{*}{$\mathrm{MRL}^{1}$} & \multirow[t]{2}{*}{ No. of positive samples } & \multicolumn{2}{|c|}{ Accepted samples } & \multicolumn{2}{|c|}{ Unaccepted samples } \\
\hline & & & & & & & No. & $\%$ & No. & $\%$ \\
\hline \multicolumn{11}{|c|}{ Raw samples } \\
\hline Breast & 10 & $15 \times 10$ & $33 \times 10^{2}$ & $24.0^{\mathrm{b}} \times 10^{2} \pm 5.2 \times 10^{2}$ & \multirow{2}{*}{$\begin{aligned} & <10^{2} \\
\text { E.S } & 1651 / 2005\end{aligned}$} & 7 & 8 & 80 & 2 & 20 \\
\hline Thigh & 10 & $17 \times 10$ & $31 \times 10^{2}$ & $25.3^{\mathrm{b}} \times 10^{2} \pm 4.2 \times 10^{2}$ & & 9 & 3 & 30 & 7 & 70 \\
\hline \multicolumn{11}{|c|}{ Half cooked samples } \\
\hline Breast & $\begin{array}{l}10 \\
10\end{array}$ & $11 \times 10$ & $45 \times 10^{2}$ & $41.7^{\mathrm{a}} \times 10^{2} \pm 2.0 \times 10^{2}$ & \multirow[t]{2}{*}{$\begin{array}{c}<10^{2} \\
\text { E.S } 3493 / 2005\end{array}$} & 5 & 7 & 40 & 3 & 30 \\
\hline Thigh & 10 & $15 \times 10$ & $56 \times 10^{2}$ & $50.0^{\mathrm{a}} \times 10^{2} \pm 3.2 \times 10^{2}$ & & 8 & 6 & 50 & 4 & 40 \\
\hline \multicolumn{11}{|c|}{ Cooked samples } \\
\hline Wings & 10 & $8 \times 10$ & $24 \times 10$ & $22.3^{\mathrm{b}} \times 10 \pm 0.9 \times 10$ & \multirow{2}{*}{$\begin{array}{c}<10^{2} \\
\text { E.S } 3493 / 2005\end{array}$} & 3 & 9 & 90 & & 10 \\
\hline Breast & 10 & $5 \times 10$ & $15 \times 10$ & $12.3^{\mathrm{c}} \times 10 \pm 1.5 \times 10$ & & 2 & 10 & 100 & - & - \\
\hline
\end{tabular}

*S. E.M $=$ Standard error of mean. ${ }^{\text {abcd }}$ values within a column with different superscript letters were significantly different at $(\mathrm{P} \leq 0.05)$.

Table 8 Statistical analytical results of Total yeast and mould $(\mathrm{cfu} / \mathrm{g})$ in examined chicken meat samples $(\mathrm{n}=30)$

\begin{tabular}{lcccccccc}
\hline Samples & No. of samples & Min. & Max. & Mean \pm S.E.M* & MRL & No. of positive samples & Accepted samples & Unaccepted samples \\
& & & & No. & $\%$ & No. & $\%$ \\
\hline Raw samples & & & & & & & &
\end{tabular}




\begin{tabular}{|c|c|c|c|c|c|c|c|c|c|c|}
\hline wings & 10 & $<10$ & $<10$ & - & E.S 1651/2005 & - & 10 & 100 & - & - \\
\hline Breast & 10 & $15 \times 10$ & $40 \times 10$ & $20.3^{\mathrm{a}} \times 10 \pm 1.0 \times 10$ & & 5 & 5 & 50 & 5 & 50 \\
\hline thigh & 10 & $25 \times 10$ & $63 \times 10$ & $41.2^{\mathrm{a}} \times 10 \pm 1.2 \times 10$ & & 3 & 7 & 70 & 3 & 30 \\
\hline \multicolumn{11}{|c|}{ Half cooked samples } \\
\hline Wings & 10 & $<10$ & $<10$ & - & \multirow{3}{*}{$\begin{array}{c}\text { Free } \\
\text { E.S 1651/2005 }\end{array}$} & - & 10 & 100 & - & - \\
\hline breast & 10 & $<10$ & $<10$ & - & & - & 10 & 100 & - & - \\
\hline thigh & 10 & $<10$ & $<10$ & - & & - & 10 & 100 & - & - \\
\hline Wings & 10 & $<10$ & $<10$ & - & \multirow{3}{*}{$\begin{array}{c}\text { Free } \\
\text { E.S 1651/2005 }\end{array}$} & - & 10 & 100 & - & - \\
\hline breast & 10 & $<10$ & $<10$ & - & & - & 10 & 100 & - & - \\
\hline thigh & 10 & $<10$ & $<10$ & - & & - & 10 & 100 & - & - \\
\hline
\end{tabular}

\section{CONCULOSION}

It could be concluded that, the half-cooked chicken meat samples contamination is more than raw and cooked samples that may be due to contamination of meat itself used in manufacture, inadequate sanitary condition during processing, bad handling, dirty equipment, polluted water, contaminated cold stores and temperature fluctuation during storage

\section{REFERENCES}

1. Allerberger, (2003): Barbecued chicken causing a multiplestate outbreak of Campylobacter jejuni enteritis. Clin. Epidemiol.Study,31(1):19-29.

2. American Public Health Associated (APHA).(2001):Compendium of Methods for the Microbiological Examination of foods Fourth edition . F.P Downes and K. Ito (editors), American Public Health Association, Washington, D.C.

3. Berrang, M.E.; Windham, W.R. and Meinersmann, R.J. (2011): Campylobacter, Salmonella and Escherichia coli on broiler carcasses subjected to a high $\mathrm{pH}$ scald and low $\mathrm{pH}$ post pick. Poult. Sci., 90:896.

4. Cardoso, W.M.; de Oliveira, W.F.; Romao, J.M.; Sampaio, F.A.C.; Carraminana, J.J.; Yanguela, J.; Blanco, D.; Rota, C.; Agustin, A.I; Arino, A. and Herrera, A. (1997): Salmonella incidence and distribution of serotypes throughout processing in a Spanish poultry slaughterhouses. J. Food Prot., 60(11): 1312-1317.

5. Capita, R.; Alonso-Calleje, C. and Prieto, M. (2007): Prevalence of salmonella enterica seovars and genovars from chicken carcasses in slaughterhouses in Spain .J. Appl. Microbiol., 103:1366-1375.

6. Cruickskshank,R.; Duguid ,J.P.;Marmion ,B.P and Swain , R.H.A.(1975):Medical Microbiology .12th Ed.Church Livingstone Edinburg, London and New York.

7. Cohen, N., Ennaji, H.; Bouchrif; Hassar, M. and Karib, H. (2007): Comparative study of microbiological qualityof raw poultry meat at various seasons and for different slaughtering processes in Casablanca (Morocco). J. Appl. Poul. Res.,16: 502-508.

8. Dookeran, M.; Baccus -Taylor,G.S; Akingbala,J.; Tameru . B. and Lammerding, A. M. (2012): Transmission of Salmonella on broiler chickens and carcasses from production to retail in Trinidad and Tobago .J Agric Biodivers Res.,1(5):78-84.

9. El -Deeb ,M.F.;EL-Glel, H.A. and Samaha, IB.A.T.(2011):Quality assurance of some poultry meat products ISSN 110-2047 Alex. J.Vet. Science 33(1)153-163.

10. Fathy-Ola(2014):Enterobacteriaceae in Poultry Meat Products. M.Sc. Thesis, Meat Hygiene, Fac. Vet. Med., Benha Univ.

11. F.;AL-Jazawi,N.;Kreidl,,P.;Dierichm, M.P.;Feierl,G.;Hein,I. and Wagner, M. Farghaly,R.M.( 1998):.Some studies on the aflatoxin- producing aspergilla in meat cold stores.Assiut Vet. Med. J.,111-120.

12. Feng, P.; Weagent, S.D. and Grant,M.A. (2002): Bacteriological Analytical Manual. Online www. Lib ncsu.edu/ pubweb/www/ETDdb/web-root/collection/available/etd-0410 2005-213953/unrestricted/etd.pdf.

13. Farghaly, R.M. (1998): Some studies on the aflatoxinproducing aspergilla in meat cold stores.Assiut vet. Med. J., 111-120.

14. GuaranTek Analytical Laboratories (2003): Microbiology. article:http:/ww.guaranteklabs.com/microbiology.htm/

15. Hassan -Ola.(2015):Microbial status of poultry carcasses from retailed outlets in Alexandria province. M.V.Sc., Thesis, Fac. Vet. Med., Cairo Univ.

16. Health Protective Agency -Corporate Plan (HPA) (2004): Available from : http://www. Hpa .org.uk/web/HPA webFile/ HPA wep C/1197021714519.

17. Heetun .I.;Goburdhun.D.and Neetoo .H. (2015):Comparative Microbiological Evaluation of Raw Chicken from Markets and Chilled Outlets of Mauritius .J.World,sPoult .Res. 5(1):10-18

18. Hegazy, S.A. (1995): Hygienic problems in handling and storage of slaughtered animal and bird. Ph.D.Thesis ,Fac .Vet.Med.,Cairo Univ.

19. Herikstad, H., Motarjemi, Y. and Tauxe, R.V (2002):Salmonella surveillance ;a gobal survey of public health serotyping .10(1989) 180-185.J.Epidimiol. Infect., 129:1-8.

20. Hossam S.A. (2012): Bacteriological and viral view of poultry meat prepared in private poultry shops. M.V.Sc., Meat Hygiene, Fac. Vet. Med., Alex. University.

21. Hotee, M.F. (2011): A critical analysis of food poisoning in Mauritius. MSc Thesis, University of Mauritius.

22. Huong, C.T.; Duong N.T. and Hien, N.T. (2009): Contamination of some bacteria isolated from chicken meat in retail markets in Hanoi and examination of the antibiotic resistance ability of Salmonella and E. coli stains isolated. J. Sci. Dev., 7:181-186.

23. International Organization for Standardization (ISO)(2001):Microbiology of food animal feeding stuffs. Horizontal methods for the enumeration of B-glucuronidase positive Escherichia coli part 2:Colony count technique at 44C using 5 bromo-4-chloro.

24. International Organization for Standardization (ISO)(2004):No. 11291-1. Microbiology of food and animal feeding stuffs- Horizontal methods for detection and enumeration of Enterobacteriaceae part 2:colony count, method.

25. International Organization for Standardization (ISO) (2013): NO.4833-1, microbiology of the food chain horizontal method for the enumeration of microorganisms .

26. International Organization for Standardization (ISO) (2017): NO. 6579-1, microbiology of food and animal feeding stuffs .Horizontal methods for detection of salmonella species.

27. International Organization for Standardization (ISO) (2017) NO.6887-2, Microbiology of food and animal feeding stuffs Preparation of test samples , Initial suspension and decimal 
dilution for microbiological examination -Part 2:Specific rules for the preparation of meat and meat products.

28. Javadi, A. and Safarmashaei, S. (2011): Microbial profile of marketed broiler meat. Middle -East J. Sci. Res., 9(5): 652656.

29. Kagambe, G.A.; Martikainen, O.; Lienemann, T.; Siitonen, A.; Traore, A.; Barro, N. and Haukka, K. (2012): Diarrheagenic Escherichia coli detected by 16-plex PCR in raw meat and beef intestines sold at local markets in Quagadougou, Burkina Faso. International Journal of food Microbiology 153:154-158.

30. Khalafalla ,F.A;Abdel- Atty ,N.S.;AbdelWanis ,S.A;andHanafy A.S;(2015): Food Poisoning Microorganisms in Chicken Broiler Meat.GlobalVeterinaria 14(2):211-218.

31. Konzacinski, L.; Hadziosmanovic M. and Zdolec , N. (2006): Microbial quality of poultry meat on the Croatain market. Vet. Arhiv., 76: 305-313.

32. Lee, G.Y.; Jang, H.I.; Hwang, I.G. and Rhee, M.S. (2009): Prevalence and classification of pathogenic Escherichia coli isolated from fresh beef, poultry and pork in Korea. Inter. J. Food Microbial., 134:196-200.

33. Mac Faddin ,J.F,(200): Biochemical testes for identification of medical bacteria .3rded. Lippincott Williams and Wilkins ,Washington, Philadelphia U.S.A.

34. Nawar, A.Z. (2007): Correlation between salmonella and sanitation level in poultry processing plants. M.V.Sc. Thesis (Meat Hygiene). Fac. Vet. Med. Benha. Univ.

35. Noha, R.M. and Gehad, F.A (2005): Bacteriology status of some chicken produce in Cairo governorate Egypt. Vet. Med. Ass., 65(3): 295-306.

36. Oumokhtar, B.(2000): Qualite, bacteriologique de viandes, d,abats, de pre,parationcarne,es et d,hui^trescommercialis ,esa,Rabat. The,se de Doctorat National, Universite, Chouaib Doukkali, Faculte des Sciences, El Jadida, Morocco

37. Rady, E. M.; Ibrahim, H. A. and Samaha I. A. (2011): Enteropathogenic bacteria in some poultry meat products. Alex. J.Vet. Sci., 33(1):175-180.

38. Ruban, S. W.; Thiyageeswaran, M. and Sharadha, R. (2010): Isolation and identification of salmonella species from retail chicken meat by Polymerase Chain Reaction .Inter. J. Microbiol. Res., 1(3):106-109.

39. Ruban, S.W. and Fairoze, N. (2011): Effect of processing condition on microbiological quality of market poultry meats in Bengalore, Ind. J. Ani. Vet. Adv., 10(2):188-191.

40. Refaie,M., Mansour ,N., EL-Naggar, A., Abdel-Aziz, A 1991. Fungal flora in Egyptian modern abattoirs Fleischwirtschaft., 77: 199-202.

41. Farhat, S. F. (2019): Prevalence of salmonella in some chicken meat products M.Sc. Thesis, Meat Hygiene, Fac. Vet. Med., Benha Univ .

42. Saad, M.S., Mousa, M.M., Edris, A.M. (1989): Microbiology of instant chicken bouillon/Stock cubes .Alex .J.Vet. Sci. $5: 227-242$
43. Saad, M. S; Edris, A. M; Hassan, M. A; Edris, S. N. (2015): Bacteriological evaluation of half cooked chicken meat products. Benha Vet. Med. J. 2: 135-140.

44. Saif. M .A. (2015): Bacterial status of Fresh marketed chicken cuts. M.Sc. Thesis, Meat Hygiene, Fac. Vet. Med., Benha Univ.

45. Saikia, P. and S.R .Joshi, 2010 .Retail market poultry meat of North -East India -a microbiological survey for pathogenic contaminants .Res. J. Microbiol 5: 36-43.

46. Samaha,I. A.; Ibrahim, H.A and Hamada, M. O.(2012): Isolation of Some Enteropathogens from Retailed poultry Meat in Alexandria Province. Alex .J. Vet. Sci., 37(1): 17-22.

47. Shaltout(2002): Microbiological aspects of semi-cooked chicken meat products. Benha.Vet. Med. Med. J. 9 (2):17-19.

48. Shaltout, F.A (2006): Microbial aspect of semi-cooked chicken meat products. Benha, Vet. Med. J., 13(2):15-25.

49. Shaltout, F. A, El-Zahaby, D. I., Lotfy,L.M., El-Shorah, H. F. (2018): Bacteriological status of chicken meat products marketed at Menofia governorate. Benha, Vet. Med. J 34, (1): $28-40$

50. Siqueira, R. S.; Dodd, C.E. and Rees, C. E. (2003): Phage amplification assay as rapid method for salmonella detection. Braz. J. Microbiol., 34: 118-120.

51. Smith, D. M. (2001): Functional properties of muscle proteins in processes poultry products .In poultry meat processing. Edd. Sams, A.R., CRC, Press.

52. Synge, B. A. (2000): Verocytoxin producing E. coli, a veterinary review. J. Appl. Microbiol .Suppl., 88:315-375

53. Vural,A.;Erkan,M.E and yesilme, S. (2006): Microbial quality of retail chicken carcasses and their products in Turkey.Medycyna Wet,62(12):1371-1374.

54. Wabeck CJ (2002): Microbiology of poultry meat products. In: Commercial chicken meat and egg production (Bell,D.D and Weaver W.D,eds),Springer Science \&Business Media Inc .pp.889-898

55. Whte, P.; McGill,K; Monahan,C. and Collins,J.D. (2014): The effect of sampling time on the levels of microorganisms recorded from broiler carcass in commercial slaughter planet .Food Microbial, 21:59

56. Yadav,M.M.; Tale,S.; Sharda, R.; Sharma ,V.; Tiwari, S. and Garg, U.K.(2006):Bacteriological quality of sheep meat in Mhow town of India .Inter. J. Food Sci Technol., 41:1234 1238

57. Zaki,H.M.; Mohamed, H.M.H. and Amal, M.A. El-Sherif (2013): Incidence of Salmonellae ,Escherichia coli and listeria monocytogenes in chicken cuts and neck in Egyptian Retail Markets .J. Egyptian Vet. Medical Association 73(2).

58. Zhang, L.; Davis, M.A. and Conner, D.E. (2001): Poultryborne pathogens: plant considerations. Poultry Meat processing chap.9. ISBN $0-8493-0120-3$, CRC Press LLC, New York, USA 